\title{
Complexity Pedagogy and e-Learning: Emergence in Relational Networks
}

\author{
Gail J. Mitchell ${ }^{1}$, Nadine Cross ${ }^{1}$, Obadiah George ${ }^{2}$, Michaela Hynie ${ }^{3}$, Kari L. Kumar ${ }^{4}$, Ron Owston ${ }^{5}$, Don Sinclair ${ }^{6}$ \& \\ Renate Wickens ${ }^{7}$ \\ ${ }^{1}$ Faculty of Health, School of Nursing, York University, Toronto, Canada \\ ${ }^{2}$ ABEL Program, Office of the Institute for Research on Digital Learning (IRDL), York University, Toronto, Canada \\ ${ }^{3}$ Faculty of Health, Psychology, York University, Toronto, Canada \\ ${ }^{4}$ Division of Extended Education, University of Manitoba, Winnipeg, Canada \\ ${ }^{5}$ Faculty of Education, Institute for Research on Learning Technologies, York University, Toronto, Canada \\ ${ }^{6}$ Digital Media Program, York University, Toronto, Canada \\ ${ }^{7}$ Department of Cinema \& Media Arts, York University, Toronto, Canada \\ Correspondence: Gail J. Mitchell, School of Nursing, York University, Toronto, Ontario, M3J 1P3, Canada.
}

Received: January 13, 2016

doi:10.5430/irhe.v1n1p206
Accepted: March 9, 2016

Online Published: March 15, 2016

URL: http://dx.doi.org/10.5430/irhe.v1n1p206

\begin{abstract}
Educators are being challenged to develop new pedagogies and e-learning platforms for engaging students, especially in higher education. Traditional Learning Management Systems (LMS), such as Moodle and Webct, have not, we suggest, offered sufficient innovation consistent with the new pedagogies required for education in the $21^{\text {st }}$ century. Current authors collaborated on a project to develop a new teaching-learning platform inspired by complexity pedagogy. Authors present the story of Daagu (original spelling is Dagu) to situate the e-learning platform within complexity thinking and extant curricular theory. Complexity pedagogy is placed in relationship with androgogy and heutogogy, as well as constructivism and connectivism. We briefly describe the complexity e-learning platform that disrupts traditional e-learning approaches by focusing on patterns of relating, diversity, conversation, reflection, and emergence among groups of learners.
\end{abstract}

Keywords: complexity pedagogy, e-learning, transdisciplinary education, networked learning, emergent learning

\section{Introduction}

\subsection{The Inspiration of Daagu}

Daagu is a tradition of the pastoral Afar people of Ethiopia. The Afari practice a process called Daagu in order to discern meaning from diverse experiences and regions (Westley, Zimmerman, \& Patton, 2006). The Daagu story of inviting diversity, discovery, and discernment within a community that depends on each other for learning, informed our work patterns over three years to develop a complexity pedagogy for delivery in an e-learning platform. We named the platform Daagu because it creates a networked community that facilitates a collaborative process of exploration of difference and discovery among students and teachers, and we wanted to honor the wisdom of the Afar people. It may be obvious, but the Daagu process, with its focus on relationships, patterns, difference, and emergent learning, is not the typical structure for higher education, or education at any level for that matter.

\subsection{Shifting from Teacher-Centric to Networked Communities of Learning}

Although shifting somewhat, our typical educational approaches, especially in North America, are still largely informed by assumptions that teachers have knowledge that they dispense to learners in carefully constructed learning activities and sequenced content modules aimed at moving students toward teacher-defined outcomes, albeit defined as learning outcomes (Doll, 1993, 2008, 2012; Ricca, 2012; Williams, Karousou, \& Mackness, 2011). Learners, in traditional educational programs, are evaluated according to how well they master the teacher-defined outcomes, and in our experience, students have become excellent consumers of teacher-defined content. We wonder how many teachers have encountered the tuned-in student who asks: What is it that you want me to know? 
Sometimes, entire courses are spent with students figuring out what teachers want them to learn and present/demonstrate, and with teachers spending time feeling good about their expertise in transmitting knowledge. Our collective team wanted to engage with students in learning how to learn, how to collaborate, how to find creative pathways for learning that can make a difference in real life. We believe that deep and meaningful learning is too restricted with teacher-defined content that prescribes pathways for learning and we wanted an alternative to traditional linear learning management systems (LMS) for engaging students in emergent growth and collaboration.

The traditional approach in teaching has been analyzed and critiqued by numerous educators and scholars (see for example, Doll, 2008; 2012; Doll, Fleener, Trueit, \& St. Julien, 2008; Kalantzis \& Cope, 2010; Ricca, 2012). The importance of the critiques are relevant in this paper because many e-learning courses and mobile apps are still modeled on prescribed outcomes, and teacher-defined content/curricula that assume students will learn what they are told and that the learning will make a difference in their life and work experiences. But content-driven curricula present a global concern, especially in higher education (Hung, 2014; Giddens \& Brady, 2007; Giddens et al., 2008). Content-driven curriculum has been linked with the following concerns: (a) a linear and behavioural view of learning that tends to be superficial and solitary (Garrison, 2006), (b) unrealistic expectations on students to keep consuming and regurgitating large amounts of information that is not necessarily relevant to their life and work (Benitez, Pauleen, \& Hooper, 2013), and (c) student dissatisfaction with prescribed content that they have not been involved in creating, and an over reliance on empirical evidence for knowing the way forward (Mitchell, 2013). The traditional model that predominates in many programs and courses in higher education provides stark contrast to the complexity pedagogy informing our teaching-learning technology.

\section{3 e-Learning and Education}

e-Learning is an increasingly attractive option for students and educators (Albidewi \& Tulb, 2014; Beetham \& Sharpe, 2013; Garrison, 2011; Means, Bakia, \& Murphy, 2014; Venkatesh, Croteau, \& Rabah, 2014 ). These authors note that e-learning increases accessibility, equity, and efficiency. And, there is mounting evidence that e-learning is as good as, or even better, than face-to-face teaching (Bell \& Federman, 2013; George et al., 2014; Meyer, 2014; Sims, 2014). There are abundant on-line resources and mobile applications that offer viable alternatives to face-to-face educational courses/programs. There is e-learning and mobile-learning (Cochrane, 2010; Park, 2011), Second Life (Wang \& Burton, 2013), MOOCs (Massive Online Open Courses) (Ebben \& Murphy, 2014; Knox, 2014), and learning ecologies/ecosystems that are transforming work places and spaces (Brown, 2002; Hung, 2014). Surrounding all these innovations is an optimism about the possibilities for enacting new pedagogies with technologies that maximize the benefits of the Internet, engagement, and social media (Fullan \& Langworthy, 2014).

Amid the growth of e-learning options there are strident calls for change in the pedagogy informing educators (Doll at al., 2008; Gueldenzoph \& Chiarelott, 2002; Fullan \& Langworthy, 2014; Hung, 2014; Ricca, 2012). Many students and educators want a different way of teaching-learning - a way that is more engaged, active, distributed, equitable, meaningful, and creative. This engaged and distributed way of educating embraces student participation as essential to the learning community - to curriculum development and the creative interplay of diversity, relationships, and transformative learning. This connected and creative way enables community conversation, student choice, non-linear pathways of collaborative learning, and thoughtful conversation about issues that are important in the lives of students.

\section{Methods}

\subsection{Complexity Pedagogy and e-Learning}

There is a substantive knowledge base about complexity pedagogy (see for example, Davis \& Sumara, 2006, 2009, 2012; Davis, Sumara, \& Luce-Kaplar, 2015; Doll, 1993, 2012; Doll et al., 2008; Doll \& Trueit, 2010; Fenwick, 2007; Hase \& Kenyon, 2000, 2007; Mason, 2008, Ricca, 2012; Seimens, 2005). We appreciate the distinctions some authors make among pedagogy, andragogy, and heutagogy (see Blaschke, 2012, Haas \& Kenyon, 2000; for example). Pedagogy has been defined by some as the process of educating children and andragogy as adult education (Wang, 2007; Wang \& Cranton, 2013), and heutogogy as self-determined education (Blaschke, 2012; Haas \& Kenyon). We also recognize and align with authors who use the term pedagogy to refer to the theory or models of teaching and learning, or the art and science of education (Beetham \& Sharpe, 2013; Fullan \& Langworthy, 2014; Morgan \& Adams, 2009).

In the interest of continuing both conversations we build on Hase and Kenyon's extension of andragogy and Blaschke's presentation of traits of Andragogy and Heutagogy. In Table 1, we offer ideas affiliated with Complexity (Relational) pedagogy that we believe help distinguish among the three models of teaching-learning (Andragogy, 
Heutagogy, and Complexity). And, we use the term complexity pedagogy with intent because we are aligned with authors (for example, Beetham \& Sharpe, 2013; Fullen \& Langworthy, 2014) who are calling for new pedagogies in the spirit of innovative ways of teaching-learning that are not contained, or sufficiently described, by the current definitions (pedagogy, andragogy, heutagogy); definitions that are directed at age groups (children versus adult) or skill sets of students (self-directed versus self-determined). For Blaschke, heutagogy is an extension of andragogy and we suggest complexity has some overlap with heutagogy, but is also disruptive of established patterns of teaching-learning.

Table 1. Andragogy, heutogogy, and complexity pedagogy

\begin{tabular}{lll}
\hline Andragogy (self-directed) & Heutagogy(Self-determined) & Complexity (Relational)* \\
\hline Single-loop learning & Double-loop learning & Infinitely recursive learning \\
\hline Competency development & Capability development & Creativity development \\
\hline $\begin{array}{l}\text { Linear design and learning } \\
\text { approach }\end{array}$ & $\begin{array}{l}\text { Non-linear design and learning } \\
\text { approach }\end{array}$ & $\begin{array}{l}\text { Emergent design and } \\
\text { collaborative learning approach }\end{array}$ \\
\hline Instructor-Learner directed & Learner-directed & Collective-directed \\
\hline Getting students to learn (content) & $\begin{array}{l}\text { Getting students to understand } \\
\text { how they learn }\end{array}$ & $\begin{array}{l}\text { Facilitating students to engage } \\
\text { in thinking and learning with } \\
\text { differences and emergent } \\
\text { insights }\end{array}$ \\
\hline
\end{tabular}

Knowledge and skill acquisition $\quad$ Self-knowledge and motivation $\quad$ Patterned, collective learning

* We extended the table to demonstrate qualities of complexity pedagogy compared to androgeny and heutogogy as defined by Blaschke.

As outlined in Table 1, we created an e-learning platform informed by complexity thinking as an alternative to the traditional LMS (Moodle) and social platforms (Wiki, Facebook, Twitter) in order to enhance our complexity pedagogy. Our intent from the beginning of the project was to create a trans-disciplinary platform for e-learning that would: grow organically, be unrestrained by disciplinary borders, and enable student engagement, participation, and the freedom to pursue personal learning within the constraints of course/program purposes. We move now to further situate complexity pedagogy with extant literature on constructivism and connectivism - the two pedagogies with some overlap and linkages with our work in complexity and e-learning.

\subsection{Constructivism and Connectivism}

The theories of constructivism and connectivism have meaningful and historical affiliations with the complexity pedagogy we have employed to construct the e-learning platform of Daagu. There are numerous sources of work for constructivism (see for example, Garrison \& Arbaugh, 2007; Cunningham \& Duffy, 1996; Doolittle \& Camp, 1999; Doolittle \& Hicks, 2003; Gueldenzoph \& Chiarelott, 2002), and for connectivism (see for example, Downes, 2008, 2010; Siemens, 2006; Siemens \& Conole, 2011; Williams, Karousou, \& Mackness, 2011). We found the work of Doolittle and Hicks (2003) helpful for elaborating on the foundational tenets of constructivism and for distinguishing among radical, social, and cognitive interpretations of constructivist scholarship and theory development. Similar to Daagu and complexity pedagogy, social constructivism focuses on the role of social interactions and community processes for knowledge development. Social constructivism focuses on the meanings embedded in communities, cultures and contexts and how this social knowledge is constructed and integrated in individuals' ways of knowing. This community-defined knowledge relies on dialogue and consensus for knowledge construction (Doolittle \& Hicks, 2003).

We have some disquiet with several social constructivist ideas however, even though there is some overlap or synergy with the complexity pedagogy ideas we embrace. Troubling to us are the notions of construction and scaffolding--the work of rational knowledge building with a focus on individual learning. The metaphor of construction surfaces a view of linear thinking that is brain-based, though socially-mediated. A second point of departure for us with social constructivism links with the idea of consensus or mediation of meaning. The common understanding of consensus is general agreement or harmony about an issue or in this case, about meaning. We agree that in this culture, at this particular time, that day-to-day words and symbols have dominant meanings. But 
consensus does not connect well with the notions of relationality, distributed knowledge, and emergence/emergent meaning -ideas important in our development of the e-learning complexity pedagogy. Emergent meanings surface in the presence of different views that are articulated among conversants, not to reach consensus but to see what novel ideas surface in the consideration of difference. According to Davis, Sumara, \& Luce-Kapler (2008), "consensus is often a bad idea when it comes to intelligent co-activity. It can demand compromise, which can lead to lowest-common-denominator solutions" (p. 67). We concur. This difference between consensus and emergence places different expectations on teachers, learners, and collaborators. According to Doolittle and Hicks (2003), "The ultimate goal of constructivism...is the development of autonomous students capable of engaging in personally meaningful inquiry resulting in viable knowledge" (p. 92). We propose that the ultimate goal of complexity (relational) pedagogy is to develop creative collaborators who know how who to clearly articulate different views with anticipation of new knowledge and possibility.

Moving on from constructivism, we now consider connectivism. In agreement with the view that constructivism does not accurately capture the approach to learning that is inspired by complexity thinking, Barnett, McPherson, \& Sandieson (2013) provide an interesting argument to support the belief that: "connectivism is an important new epistemology for education" (p. 687). As expected, connectivism (Downs, 2008, 2010; Hung, 2014; Siemens, 2005; Siemens \& Conole, 2011) with its foundations in complexity thinking has more in common with the e-learning relational technology we have been developing. The areas of overlay between our e-learning complexity platform and connectivism are:

- Emergence (of the novel, new patterns/relationships, understanding), learning ecologies where context and particulars facilitate connected growth

- Wholeness, everything interconnected, dynamic, flowing, co-evolving, open networks of relations/connections/possibility and non-linear change

- Importance of diversity, perturbations, and challenge to reflective and unreflective responsiveness, and iterative growth

- Learning is a collective and connected endeavor, a process of engagement and collaboration, interactions among neighbours are generative, creative, and unpredictable yet open to reflective understanding. Neighbours in this context are not referring to persons but "the neighbours that interact are ideas, hunches, queries, and other manners of representation" (Davis \& Sumara, 2009, p. 40).

Emergent knowledge also surfaces in social spaces, especially spaces among the different or diverse. Emergence is non-linear, unexpected, novel, or newly created - not by consensus or construction, but by chaos and self-organizing processes that are generative. The notion of chaos has relevance to our work. For instance, Haskell (2004) speaks of freefall pedagogy to help teachers imagine the leap of faith it takes to shape a context for learning and then letting it happen - a deliberate letting go that creates space for learning to emerge. By engaging spaces of possibility with anticipation of new insights, educators can help others to make new connections that enable deeper knowledge and broader understandings that cannot be controlled, predicted, or prescribed. The learning we are witnessing in the Daagu platform has the qualities anticipated with complexity pedagogy in that students' are describing shifts in understandings and applications of knowledge in new ways across different contexts.

\subsection{Situating Complexity in eLearning Scholarship}

Our complexity informed e-learning platform aligns with multiple theorists and scholars in expected and unexpected ways. We think it is important to locate the work we have developed in order to advance the dialogue/ conversation about how different pedagogies can accelerate emergent, deep, and meaningful learning. Over the three years of development, and two years of using Daagu, we have seen that complexity pedagogy enables emergent learning in spaces of difference and diversity, and this emergent learning is connected with the teacher's critical role of perturbing, questioning, and engaging with participants and details in the learning collective. (Laidlaw, 2004). We will now describe spaces and processes of the Daagu platform and offer some examples of how the complexity pedagogy is enacted with students.

\subsection{Complexity and e-Learning}

The Daagu platform of complexity houses three main spaces: personal, group/course, and global. The personal space, as expected, is a private area where learners develop profiles and gather thoughts, ideas, and resources that can later be distributed, if desired, to a group for discussion. Discussions in the platform are initiated by users and grow according to contributor design. The group or course space enables discussion and exploration of topics/issues among learners enrolled in a course or activity. The global space crosses geographical, disciplinary, and 
organizational boundaries such that all users of the system can search and participate in discussions by making new connections and contributions. Teachers initiate collaborative inquiry with students by presenting the big ideas or perspectives relating to the topic of study and proposing some key questions. The educator's role is to set the liberating-constraints (Davis \& Sumara, 2009; Doll, 2012) that will connect ideas with the processes of discovery and place limitations on the possibilities of an engaged inquiry.

For example, in a course on global health, the perspectives or big ideas posed by the educator might be: health and poverty, health and gender, health and politics, and health and culture. Once these big ideas or perspectives are crafted and briefly described, the teacher may start a discussion, using one or more perspectives by posing questions that invite students to reflect on how they want to better understand these big ideas. To continue with our example, the teacher may start a discussion about poverty and health by presenting a narrative story about a man who lives in a large urban city; several health and social justice issues are introduced within the context of the man's life. The teacher offers a link to a YouTube describing urban poverty and includes various images about poverty and how it shapes community health in different cultures. Students are then invited to select the context for their own exploration of poverty and health. A student may want to examine poverty and health experiences among single mothers, for transgendered community members, for children with disabilities, or for the elderly in rural Canada. The options for students are as varied as their interests and passions about the topic/idea(s), and as each student, or group, embarks on their own inquiry, they have the resources of the World Wide Web (www) to aid in their journey and their learning. As students discover connections about poverty and health that they had not seen or understood before, they share their insights and understandings with others. Students also share links to additional articles, Youtube videos, Ted Talks, documentaries, images that have helped them to see things in a new light. In this way, the curriculum relating to the big ideas (perspectives) begins to grow and expand with new connections among ideas and among students as discussions unfold.

This diversity of inquiries about poverty and health brings multiple contexts into conversation, and when connected or perturbed by the teacher's commitment to facilitating insights among spaces of difference, the conversations generate new learning - emergence. Emergent learning is recognized when a shift in understanding is articulated or in situations when new connections are made among divergent ideas, different contexts, or neighbours. Davis and Phelps (2004) wrote of emergence as "instances of webbed, nested, multilayered narratives that become more intricately dense and full of possibility" (p.4) The collective of teacher and learners do not dwell within an either/or frame that could limit learning. Instead, the collective considers both/and (all) the ideas as a place for creative, deep learning. The relations experienced within the collective of complexity are open, dynamic, and reflexive (Trueit, 2008). The relational experience of both/and affords insights, shifts of authority away from teacher to collective, movement from certainty to inquiry/questioning, and new knowledge or application to life and work situations. We have seen that in the non-linearity of the complexity pedagogy, learners' patterns of conversing and sharing shift away from teacher-student to student-student patterns of relating and reflecting.

The complexity platform will facilitate distributed learning that crosses time, geography, and disciplinary borders. In the example of a course on Global Health, students might have access to discussions and resources from other courses and other disciplines that have contributed to the global network of Daagu, a network that grows organically. With the help of multiple tags and filters, students wil be able to search the Global Network to explore new connections or links with ideas not yet considered. For instance, the legal rights of new immigrants in some countries prohibit access to certain health resources, and students have access to discussions on this topic that may have originated in a law course or a course in social work. As students make new connections among ideas and consider how those ideas may be relevant in his or her personal context of study or life, the nature of emergent learning in spaces of difference broadens and becomes more dense and connected.

Our thinking is aligned with Richardson and Postman (2013) who suggested that, technology has the potential to transform education through creativity, as opposed to seeing technology as merely a way to dispense information and manage students. Technology is a beautiful thing when it connects people, engages imaginations, and sparks creativity. And we have also been influenced by the work of Kalantzis \& Cope (2010) who link education with the needs of a knowledge society, a society that requires relationships of values, flexible and aware workers who show ongoing creativity and initiative, comfort with ambiguity, and who can traverse global and social webs and disciplinary fields. Further, these authors call for a paradigm of transformative learning by design, where there are multiple access points and project sites, extensive collaborations among students, and multiple knowledge processes and activities for engaging ideas and possibilities. Differences, engagement, multi-modality and the remaking of self are hallmarks of Kalantzis \& Cope's vision for leaning and consistent with our vision of emergent learning. 
The e-learning platform described here offers proximity between the teacher and learner that may be lost with other online platforms. This proximity along with the teacher's presence as perturber and connector addresses concerns that online teaching-learning lacks interactivity and the open-endedness found in a face-to-face class (Newstock, 2013) The teacher holds a learning place along with the students as all participants connect personal ideas and capabilities within the complexity platform. The teacher and learners create pathways for deep learning, pathways that provide trans-disciplinary opportunities for learning in worlds of education, practice, and work.

\section{Results}

\subsection{Emergent Learning in Spaces of Difference}

A critical focus for the vision of complexity inspired discovery in Daagu is on emergent learning. Needless to say there are many educators, authors, theorists that write of emergence/emergent learning. (see Byrne, 2014; Doll, 2012; Goldstein, 1999; Trueit, 2008; Osberg, 2009; Osberg \& Beista, 2008). Many authors contribute ideas concerning the key to emergence or the implications for emergence. This section of the paper will describe emergence as it was identified within the space of complexity pedagogy and e-learning with Daagu.

As described above, Daagu is a virtual place of possibility for new knowledge creation within the dynamic interaction and relations of the participants. It is not a place of common ground. Rather, it is a place where difference (diversity of persons' views that are clearly articulated) creates spaces of possibility through conversation and reflection. It is the engagement with diverse perspectives/knowledge that unsettles, complicates, perturbs and calls for further conversation (Trueit, 2008). And it is in the conversation of these perturbations where discernment and new meanings and understanding emerge.

Students engaging in the complexity pedagogy in Daagu are able to identify shifts in understanding with a click on a lightbulb that is embedded in conversations. The educator's role is to facilitate these shifts by offering perturbations, questions, alternative views, and new connections. Students have taken advantage of the lightbulb icon to share their shifts in understanding and typically, the shift and new insight is accompanied by the text that describes what happened. In a course on Women's Health, a very diverse student community contributed numerous issues of women's health in different contexts and so the contributions to shifts in understanding were notable. In each discussion thread the numbers of emotional icons and light bulb clicks show up in the first frame of the discussion.

Another way that emergence was recognized in the complexity-inspired space was when students started conversations that they were passionate about within the confines of the course learning outcomes. The Daagu platform grows over the course of study in an organic way depending on the contributions students bring to the curriculum. In this way, emergency is recognized as a spontaneous growth of curriculum that is inspired by the conversations and perturbations happening in the networked community of Daagu. Figure 1 shows a screen shot of an undergraduate nursing course. Typically the educator begins a conversation or two with a few provocative papers, YouTubes, or TedTalks and then the students bring content that resonates for them and that they believe will inspire additional conversation and learning. As shown in Figure 1, students started conversations individually and in groups according to their interests and selections. 


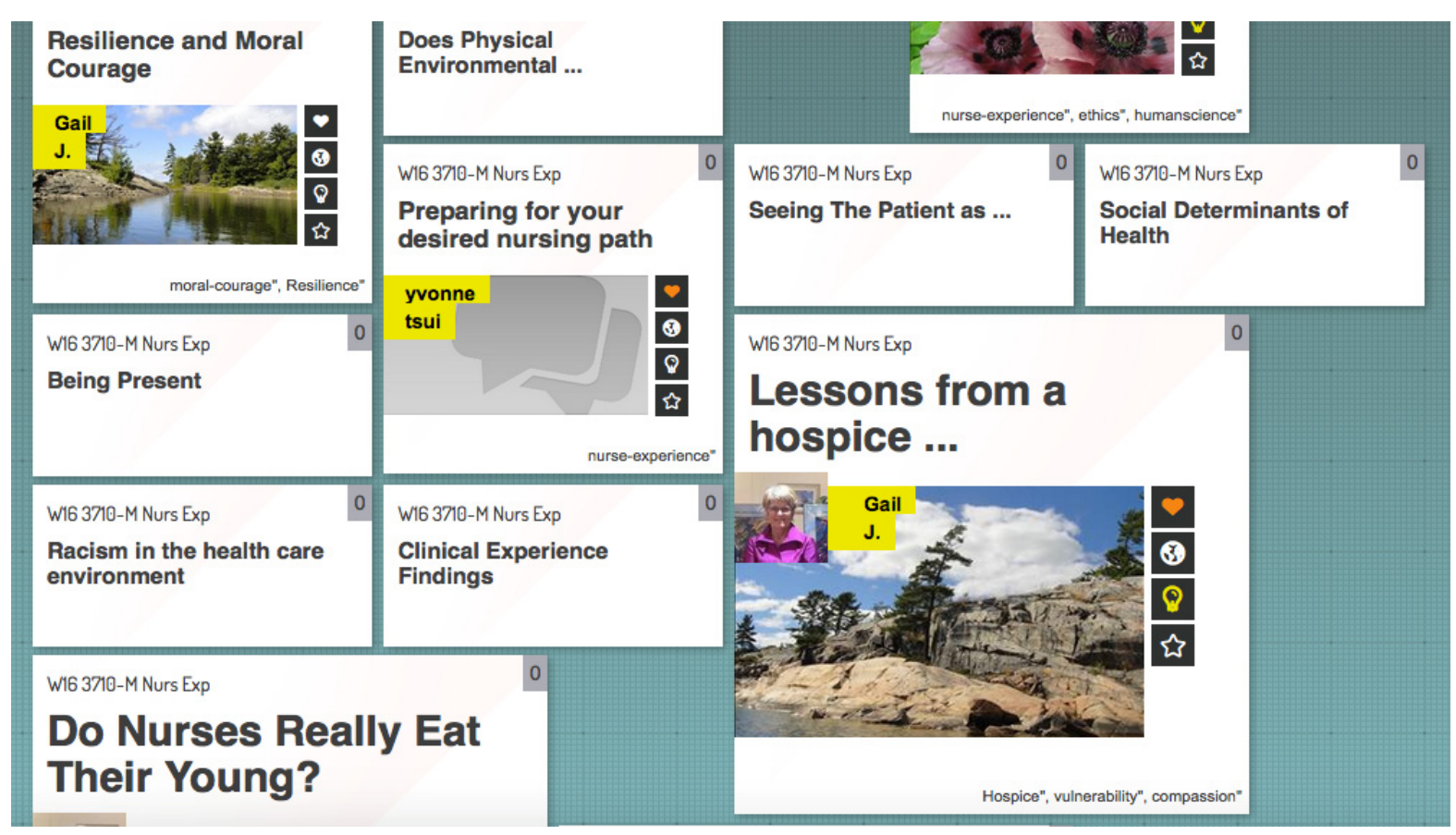

Figure 1. Screen shot of organically growing curriculum in the Daagu platform

\section{Discussion}

Teaching for emergence is a practice of attending, through listening and attunement, to the patterns among the collective and acting on opportunities to make new connections, provoke description of unarticulated assumptions, and make sense of the possible learning that is showing up (Aoki, 2000). Important for all of us in light of teaching in complexity, is that emergent learning is a space of "both-and" that moves us to a place beyond the dualities, binaries, and either/or categories of modernist discourse. Instead, complexity thinking helps us to see and understand the "patterns of relationships and how emergence brings forth a reflexive criticality to the dominant discourse in teaching and learning" (Trueit, 2008, p.146).

Complexity pedagogy invites teachers to a place of possibility-with-uncertainty, where teachers invite students, through resources and critical questions, into spaces of thinking, challenging, and conversing with others. The resources act as constraints and yet act as liberating possibilities of how, when, what, and with whom the learners will engage with the initial content and each other. It is the interplay between the constraining and liberating aspects of the created space that emergence of new insights and aha moments are experienced. Teachers also experience learning about the learning process, the possibilities that accompany students' experiences of freedom of context, and the openness that accompanies questioning without the judgment of right-wrong thinking. Teachers witness student discovery and the interplay of ideas as well as the consequences and applications of new learning. And, teachers experience the frustration of students who have been influenced by a cultural view of knowledge as substance to be transmitted and returned, rather than as ideas with which to play and grapple. Complexity views knowledge more as possibility or capacity for future actions (Davis, Sumara, \& Luce-Kaplar, 2015), actions that are worked out with others in the context of real life and the big issues that occupy us on a day to day basis.

Complexity pedagogy moves us away from the individual expert who passes on received knowledge, toward learning collectives of persons who complicate and participate in emergent knowing. Emergence in the Daagu platform is a participatory process of conversation where patterned relations can be understood. The diversity/difference of the teachers and learners, ideas, notions, enacted within the collective bring forth rich, generative possibilities. Teachers and learners bring insights from traditional thinking in conversation with diverse perspectives so that new insights emerge. The Daagu e-learning platform offers a place where the potential of the collective exceeds the individual learners/teachers, and a central organizer, as in traditional higher education contexts. It does not limit the potential where learners/teachers are called to become aware of the connections among the seemingly disparate ideas/phenomena. New understanding surfaces/emerges with extended connections among ideas, articulated actions, and possibilities for action. 
The Daagu platform has the potential to encourage and support border crossing to trans-disciplinarity. If social ecologies really can exist in learning organizations, diverse views and troubling questions will be expected and valued. This collective exploration and wisdom could be particularly useful in large organizations such as hospitals where numerous disciplines collect and collaborate to deliver care and service. The Daagu platform shifts authority, hierarchy, and distributes expertise in ways that could, we propose, help to address the complex issues linked with things like patient safety and quality of care.

\section{Conclusion}

Complexity pedagogy has been a useful informant for our team to translate ideas into an e-learning platform that supports networked learning and organic, non-linear growth of curriculum that students and teachers find interesting, provocative, and inspiring. Complexity pedagogy is not for everyone. We have learned that some teachers prefer to deliver content. And some students want teachers to tell them what and how to think. How much of these preferences are habitually based is open for speculation. The calls for change and for new ways of learning, however, do propel us to keep trying to push the possibilities for learning. The future challenges we face with complexity and Daagu relate to developing new ways of showing how ideas and students are connected. We also have tested the Global network in the Daagu platform to enable trans-disciplinary border crossing. The possibilities for the trans-disciplinary exchanges will open further ways for students to engage and learn. Complexity and e-learning show how education can move to be more community based, innovative, and meaningful.

\section{Acknowledgements}

Authors would like to acknowledge the Academic Innovation Fund at York University who funded the creation of the Daagu prototype and the Ontario Centres of Excellence who funded the current version of the user-interface.

\section{Competing Interests/Conflicts of Interest}

Authors are inventors of the Daagu platform and although still a research project, the platform is on a track for possible commercialization.

\section{References}

Albidewi, I., \& Tulb, R. (2014). Promise and challenge of e-learning - Literature review. ESJ, 10(1), 210-217.

Aoki, T. (2000). Locating living pedagogy in teacher 'research': Five metonymic moments. New York, NY: Peter Lange, p. 1. http://www.jstor.org/stable/42978048

Barnett, J., McPherson, V., \& Sandieson, R. M. (2013). Connected teaching and learning: The uses and implications of connectivism in an online class. AJET, 29(5). http://dx.doi.org/10.1234/ajet.v29i5.243

Beetham, H., \& Sharpe, R. (Eds.) (2013). Rethinking pedagogy for a digital age. Designing for 21st century learning. London, UK: Routledge Taylor \& Francis. Retrieved from http://samples.sainsburysebooks.co.uk/9781136158049_sample_493214.pdf

Bell, B. S. (2013). Federman, J. E. E-learning in Postsecondary Education. The Future of Children, Spring, 23(1), 165-185. Retrieved from http://www.jstor.org/stable/23409493

Benitez, E., Pauleen, D., \& Hooper, T. (2013). From Information Gatherers to Knowledge Creators: The Evolution of the Post-Graduate Student. EJKM, 11(2). Retrieved from www.ejkm.com

Blaschke, L. M. (2012). Heutagogy and lifelong learning: A review of heutagogical practice and self-determined learning. 2012. IRRODL, 13(1). Retrieved from http://www.irrodl.org/index.php/irrodl/article/view/1076

Brown, J. S. (2002). Growing Up Digital: How the Web Changes Work, Education, and the Ways People Learn. USDLA, 16(2). Retrieved from http://www.usdla.org/html/journal/FEB02_Issue/article01.html

Byrne, D. (2014). Thoughts on a pedagogy of complexity. Complicity: An International Journal of Complexity and Education, 11(2). Retrieved from https://ejournals.library.ualberta.ca/index.php/complicity

Cochrane, T. (2009). Mobile Web 2.0: Bridging Learning Contexts. 2010. Hershey, PA: Information Science Reference, p. 123.

Cunningham, D., \& Duffy, T. (1996). Constructivism: Implications for the design and delivery of instruction. AECT, 170-198. Retrieved from http://www.aect.org/edtech/ed1/pdf/07.pdf

Davis, B., \& Phelps, R. (2007). Participating consciousness and complicity. Complicity: An International Journal of Complexity and Education, 4(1), 1-4. Retrieved from https://ejournals.library.ualberta.ca/index.php/complicity

Davis, B., \& Sumara, D. (2006). Complexity and education: Inquiries into learning, teaching, and research. New York, NY: Routledge.

Davis, B., \& Sumara, D. (2009). Complexity as a theory of education. TCI, 5(2), 33-44. 
Davis, B., \& Sumara, D. (2012). Fitting teacher education in/to/for an increasingly complex world. Complicity: International Journal of Complexity and Education, 9, 30-40. Retrieved from https://ejournals.library.ualberta.ca/index.php/complicity

Davis, B., Sumara, D., \& Luce-Kapler. (2015). Engaging minds: cultures of education and practices of teaching (3rd ed.). New York, NY: Routledge.

Doll, W. E. (1993). A post-modern perspective on curriculum. New York, NY: Teachers College.

Doll, W. E. (2008). Looking back to the future: A recursive retrospective. JCACS, 6(1), 3-20.

Doll, W. E. (2012). Complexity and the culture of curriculum. Complicity: International Journal for Complexity and Education, 9(1), 10-29. Retrieved from https://ejournals.library.ualberta.ca/index.php/complicity

Doll, W. E., Fleener, M. J., Trueit, D., St. Julien, J. (Eds.) (2008). Chaos, complexity, curriculum, and culture. A conversation. New York, NY: Peter Lang.

Doolittle, P. E., \& Camp, W. G. (1999). Constructivism: The career and technical education perspective. Retrieved from http://scholar.lib.vt.edu/ejournals/JVTE/v16n1/doolittle

Doolittle, P. E., \& Hicks, D. (2003). Constructivism as a theoretical foundation for the use of technology in social studies. Theor Res Soc Educ., 31(1), 72-104. http://dx.doi.org/10.1080/00933104.2003.10473216

Downes, S. (2008). Places to go: Connectivism \& connective knowledge. IJOE, 5(1). Retrieved from http://nsuworks.nova.edu/cgi/viewcontent.cgi?article $=1037 \&$ context $=$ innovate

Downes, S. (2010). New technology supporting informal learning. Journal of Emerging Technologies in Web Intelligence, 2(1), 27-33. http://dx.doi.org/10.4304/jetwi.2.1.27-33

Ebben, M., \& Murphy, J. S. (2014). Unpacking MOOC scholarly discourse: a review of nascent MOOC scholarship. Learning, Media and Technology, 1-18. http://dx.doi.org/10.1080/17439884.2013.878352

Fenwick, T. (2007). Puzzling 'responsibility' in complexity and education. Proceedings of the Complexity Science and Educational Research Conference, Feb 18-20, Vancouver B.C.: 99-110. Retrieved from www.complexityandeducation.ca

Fullan, M., \& Langworthy, M. (2014). A rich seam. How new pedagogies find deep learning. London: Pearson. Retrieved from http://michaelfullan.ca/wp-content/uploads/2014/01/3897.Rich_Seam_web.pdf

Garrison, D. R. (2011). E-learning in the 21st century: a framework for research and practice. Taylor \& Francis.

Garrison, D. R., \& Arbaugh, J. B. (2007). Researching the community of inquiry framework: review, issues, and future directions. Internet High Educ., 10(3), 157-172. http://dx.doi.org/10.1016/j.iheduc.2007.04.001

George, P. P., Papachristou, N., Belisario, J. M., Wang, W., Wark, P. A., Cotic, Z., ... Car, J. (2014). Online eLearning for undergraduates in health professions: A systematic review of the impact on knowledge, skills, attitudes and satisfaction. J Glob Hlth., 4(1). http://dx.doi.org/10.7189/jogh.04.010406

Giddens, J. F., \& Brady, D. P. (2007). Rescuing nursing education from content saturation: The case for a concept-based curriculum. J Nurs Educ., 46(2), 65-69.

Giddens, J., Brady, D., Brown, P., Wright, M., Smith, D., \& Harris, J. (2008). A new curriculum for a new era in nursing education. Nurs Educ Persp., 29, 200-204.

Goldstein, J. (1999). Emergence as a construct: History and issues. Emergence: Journal of Complex Issues in Organizational Management, 1, 49-72. http://dx.doi.org/10.1207/s15327000em0101_4

Gueldenzoph, L., \& Chiarelott, L. (2002). Using educational technology to improve constructivist instruction in higher education. JECT, 13, 43-56.

Hase, S., \& Kenyon, C. (2000). From andragogy to heutagogy. Ultibase Articles, 5(3), 1-10.

Hase, S., \& Kenyon, C. (2007). Heutagogy: A child of complexity theory. Complicity: An International Journal of Complexity and Education, 4(1). Retrieved from https://ejournals.library.ualberta.ca/index.php/complicity

Haskell, J. (2004). Enacting freefall pedagogy: tasting the air of possibility. Educational Insights, 9(1). Retrieved from http://www.ccfi.educ.ubc.ca/publication/insights/v09n01/articles/haskell.html

Hung, N. M. (2014). Using ideas from connectivism for designing new learning models in Vietnam. IJIET, 14(1), 76-82. http://dx.doi.org/10.7763/IJIET.2014.V4.373

Kalantzis, M., \& Cope, B. (2010). The teacher as designer: pedagogy in the new media age. E-Learning and Digital Media, 7(3). http://dx.doi.org/10.2304/elea.2010.7.3.200 
Knox, J. (2014). Digital culture clash: "massive" education in the E-learning and Digital Cultures MOOC. Distance Education, (ahead-of-print), 1-14.

Laidlaw, L. (2004). On the importance of little details: complexity, emergence and pedagogy. Educational Insights, 9(1). Retrieved from http://www.ccfi.educ.ubc.ca/publication/insights/v09n01/articles/laidlaw

Mason, M. (2008). Complexity theory and the philosophy of education. Oxford, UK: Wiley Blackwell. http://dx.doi.org/10.1002/9781444307351

Means, B., Bakia, M., \& Murphy, R. (2014). Learning online. What research tells us about whether, when and how. New York, NY: Routledge Taylor \& Frances.

Meyer, K. A. (2014). Quality in distance education: focus on on-line learning [Internet]. ASHE-ERIC Higher Education Report. Jossey-Bass Higher and Adult Education Series. Retrieved from http://184.168.109.199:8080/xmlui/bitstream/handle/123456789/2126/ED470042.pdf?sequence=1

Mitchell, G. J. (2013). Implications of holding ideas of evidence-based practice in nursing, NSQ, 26, 143-152. http://dx.doi.org/10.1177/0894318413477139

Morgan, D., \& Adams, J. (2009). Pedagogy first: Making web technologies work for soft skills development in leadership and management education. JILR, 20(2), 129-155.

Newstock, S. L. (2013). A plea for 'close learning'. Liberal Education, 99(4). Retrieved from www.aacu.org/liberaleducation/le-fals/newstock.cfm

Osberg, D. (2009). Enlarging the space of the possible around what it means to educate ad be educated. Complicity: An International Journal of Complexity and Education, 6(1). Retrieved from https://ejournals.library.ualberta.ca/index.php/complicity

Osberg, D., \& Biesta, G. (2008). The emergent curriculum: navigating a complex course between unguided learning and planned enculturation. JCS, 40(3), 313-328. http://dx.doi.org/10.1080/00220270701610746

Park, Y. (2011). A pedagogical framework for mobile learning: categorizing educational applications of mobile technologies into four types. IRRODL, 12(2). 78-102.

Ricca, B. (2012). Beyond teaching methods: a complexity approach. Complicity: An International Journal of Complexity and Education, 9(2), 31-51. Retrieved from https://ejournals.library.ualberta.ca/index.php/complicity

Richardson, W., \& Postman, N. (2013). Students first, not stuff. EL, 70(6). Retrieved from http://www.ascd.org/publications/educational-leadership/digitalel.aspx

Siemens, G. (2005). Connectivism: a learning theory for the digital age. ITDL, 2(1), 3-10. Retrieved from http://www.itdl.org/

Siemens, G., \& Conole, G. (2011). Special issue - connectivism: design and delivery of social networked learning. IRRODL, 12(3), I-IV. $\quad$ Retrieved from http://ezproxy.umuc.edu/login?url=http://search.ebscohost.com/login.aspx?direct=true\&db=edswss\&AN=0002 $90996300001 \&$ site $=$ eds-live $\&$ scope $=$ site

Sims, R. (2014). Design alchemy. Transforming the way we think about learning and teaching. New York, NY: Springer. http://dx.doi.org/10.1007/978-3-319-02423-3

Trueit, D. (2008). Beyond simple order: complexity and postmodern politics. JCACS, 6(1). Retrieved from http://www.jcacs.com/

Venkatesh, V., Croteau, A. M., \& Rabah, J. (2014). Perceptions of effectiveness of instructional uses of technology in higher education in an era of Web 2.0. Proceedings System Sciences (HICSS), 47th Hawaii International Conference, Jan 6-9, IEEE. http://dx.doi.org/10.1109/hicss.2014.22

Wang, F., \& Burton, J. K. (2013). Second life in education: a review of publications from its launch to 2011. BJET, 44(3), 357-371. http://dx.doi.org/10.1111/j.1467-8535.2012.01334.x

Wang, V. C. (2007). Adult learners' perceptions of the teaching preferences of online instructors. ITDL, 4(6).

Wang, V.C., \& Cranton, P. (2013). Traditional teaching or innovative teaching via technology? LPQ, 2(1), 1-13. Retrieved from http://www.sageperformance.com/ojs/index.php/LPQ

Westley, F., Zimmerman, B., \& Patton, M. Q. (2006). Getting to maybe: how the world is changed. Random House: Toronto.

Williams, R., Karousou, R., \& Mackness, J. (2011). Emergent learning and learning ecologies in Web 2.0. IRRODL, 12(3), 39-59. Retrieved from http://www.irrodl.org/index.php/irrodl/article/view/883/1686 